AMERICAN JOURNAL OF FOOD AND NUTRITION

Print: ISSN 2157-0167, Online: ISSN 2157-1317, doi:10.5251/ajfn.2011.1.2.74.78

(C) 2011, ScienceHuß, http://www.scihub.org/AJFN

\title{
Total contents of major minerals in the nature yoghurt and in the yoghurts with the date powder of three dry varieties
}

\author{
Hayat Amellal-Chibane ${ }^{1 ;}$ Salem Benamara ${ }^{2}$
}

Science Faculty, Boumerdes University, Algeria

Laboratory of Sweets Technology, Valorization, Physical-Chemistry of Biological Materials

and Biodiversity

\begin{abstract}
In this paper we report on the content of major minerals (calcium, magnesium, sodium, potassium, iron and zinc) in the nature yoghurt (without sugars) and three yoghurts added with date powders. The latter's were from three dry date varieties (Mech-Degla, Degla-Beida and Frezza). The elements determination was carried out using atomic absorption spectrometry after mineralization processing. Total mineral content showed a great difference between the yoghurt nature and yoghurts enriched by date powder fruits. In the yoghurts added with date powder, following results were found (in $\mathrm{mg} / \mathrm{Kg}$ ): calcium (2213.31-2938.67), sodium (783.37-959.36), potassium (725.68-771.77), magnesium (169.54-267.85), iron (9.6-11.52), zinc (1.29-7.93). Concerning the natural yoghurt the values obtained were (in $\mathrm{mg} / \mathrm{Kg}$ ): calcium (1950.41), Sodium (684.72), potassium (540.58), magnesium (132.16), iron (5.26), zinc (0.35). These results are in positive interrelationship with those of the rheological properties.
\end{abstract}

Keywords: Yoghurt, calcium, magnesium, sodium, potassium, iron, zinc, date.

\section{INTRODUCTION}

Recent years have witnessed a significant use of plants, mainly fruits. They arouse a growing interest among consumers, dieticians and nutritionists. They are used, moreover, in the preparation of food of high energy value and dietetics: "yoghurt, flour for babies, jams, marmalades."

It should be noted that products based on dates have already been developed. These include Ketchup (Mikki et al, 1987), biscuits (Siboukeur, 1997), ice (Greiner, 1998), Tamarheep (a mixture of flour of dates and milk) (El Nakhal et al 1987), flour of dates and yogurt with extract of dates ( Benamara et al ,2004).

This work aims to enhance the value of the dry dates: Mech-Degla, Degla-Beida and Frezza in particular, the objective being their eventual transformation into powder after drying under vacuum. This powder is used as an ingredient for the enrichment of yoghurt. The targeted objectives are numerous: Substitution of granulated sugar, taking in to account the high sugar content of certain date varieties (70 \% dry basis); (2) Substitution of artificial flavourings usually added to yoghurt, (3) Using the powdered dates as texture agent (thickening and / or gelling) having regard to its richness in fibre and pectin; (4) enrichment of the prepared yoghurt with dates minerals $(\mathrm{Ca}, \mathrm{P}, \mathrm{K}, \mathrm{Fe}, \ldots)$ and other substances biologically active (Group B vitamins, essential amino acids, polyphenols).

With these objectives, we expect to result to the formulation of a product which is functional in line with the expectations of consumers in the modern era.

It is well known that fresh fermented dairy products such as yoghurt are widely consumed foods in many countries. The yogurt is one of the most dairy products sold on the market because of the diversification of the range available: reduced fat yoghurt, probiotic yoghurt, yoghurt mousse, ice cream yoghurt, liquid yoghurt for drinking (Fiszman et al, 1999). The yoghurt itself, in addition to its nutritional importance, has been identified as a healthy food due to its beneficial alive bacteria .These is in competition with pathogenic bacteria in both the food and the environment (Tamime and Robinson, 1985)

\section{MATERIALS AND METHODS}

Dates varieties: The varieties of dates included in this study are widespread in the palmgrove of SouthEast region of Algeria. Three varieties were chosen: Mech-Degla, Degla-Beida and Frezza.

The Mech-Degla variety has a sub-cylindrical form, slightly narrowed at the end. At maturity, it becomes rather light beige tinged with a little light brown. The 
epicarp is wrinkled, little bright and easily broken. The mesocarp is of little consistency, dry and of fibrous texture (Buelguedj, 1996) .

Degla-Beida is slender. It is flat on the side of the perianth and narrowed on the other end. A full maturity, it is beige. The epicarp is thick and smooth. The mesocarp is fleshy, with a dry consistency and a floury texture (Buelguedj, 1996).

The Frezza dates ( consisting really in Deglet Nour variety dried on the tree when weather conditions are unfavourable) has a slender form sometimes eggshaped, slightly flattened at the perianth side. At maturity, the date is amber with a smooth bright epicarp, easily folded once the dates softened. The mesocarp is thin with a dry consistency and a fibrous texture (Buelguedj, 1996).

The choice of these varieties is justified by their good taste, their abundance at the national level and their preservation ability (dry dates).
The milk used for the manufacture of yoghurt: The milk used is a full cream dehydrated powdered milk brand NESPRAY.

The lactic ferments: The lactic ferments used are represented by Streptococcus thermophilus and Lactobacillus bulgaricus at a freeze-dried state.

The date powders used for manufacture of yoghurt: The date powders are obtained after drying at $80^{\circ} \mathrm{C}$ followed by grinding and sifting.

Yoghurt Making : The preparation of yoghurt is made in a laboratory respecting the diagram for making standard yoghurt with a modification concerning the substitution of white sugar with powdered dates. Adding it takes place before heat treatment. The adapted recipe is the one determined within the work which is included in our research project and patented in 2004 and it is presented (with standard yoghurt as a reference) in table 1.

Table 1: Recipe of standard yoghurt and yoghurt with the dates powders $(\mathbf{1 0 0 g})$

\begin{tabular}{|l|l|l|l|l|l|}
\hline Recipe & $\begin{array}{l}\text { Powder of } \\
\text { milk (g) }\end{array}$ & $\begin{array}{l}\text { Sugar } \\
(\mathrm{g})\end{array}$ & $\begin{array}{l}\text { Powder of dates } \\
(\mathrm{g})\end{array}$ & $\begin{array}{l}\text { Water } \\
(\mathrm{ml})\end{array}$ & $\begin{array}{l}\text { Lactic } \\
\text { Ferment } \\
(\%)\end{array}$ \\
\hline $\begin{array}{l}\text { Standard Yoghurt } \\
\begin{array}{l}\text { Yoghurt with Powder of } \\
\text { dates }\end{array}\end{array}$ & 13.7 & 0 & 0 & 100 & 0.03 \\
\hline
\end{tabular}

Analysis of minerals: The mineral elements are determined by Atomic Absorption Spectrophotometry. In atomic absorption concentration is derived from measuring the absorption of light by atoms of the element stayed in the fundamental state when they are illuminated by a suitable source of light. The measurement of light intensity is made at a specific wavelength of the element to be determined.

\section{RESULTS AND DISCUSSION}

The minerals content of the four yoghurts produced are illustrated in Table.2:

The analysis of results given in Table. 2 highlighted the following points:

The three-yoghurts to which we added powdered dates are richer in minerals than the plain yoghurt.
This is may be due to the richness of the dates in minerals.

- The content of calcium YF seems very high as those of other yogurts (YB, YM, YT), since it is equal to $2938.67(\mathrm{mg} / \mathrm{kg})$ against 2350.25, 2213.31 and 1950.41 ( $\mathrm{mg} / \mathrm{kg}$ ) for YB, YM and YN respectively. The calcium in plain yoghurt is variable: $1525 \mathrm{mg} / \mathrm{kg}$ (Wang and Singh, 1978), $1355 \mathrm{mg} / \mathrm{kg}$ (Moreno Rojas et al, 1993), $2000 \mathrm{mg} / \mathrm{kg}$ (Buttriss, 1997) and $1112 \mathrm{mg} / \mathrm{Kg}$ (Garcia Martinez et al, 1998). (Sanchez-Segarra et al, 2000) have reported values of $990 \mathrm{mg} / \mathrm{kg}$ for a strawberry yogurt, $1009 \mathrm{mg} / \mathrm{kg}$ for a yogurt with blackberries, $1047 \mathrm{mg} / \mathrm{kg}$ for a yogurt added to a mixture of fruits, $917 \mathrm{mg} / \mathrm{kg}$ for a yoghurt with normal peaches, $881 \mathrm{mg} \mathrm{/} \mathrm{kg} \mathrm{for} \mathrm{a}$ yoghurt with the yellow peaches, $964 \mathrm{mg} / \mathrm{kg}$ for a yogurt with red peaches and $1056 \mathrm{mg} / \mathrm{kg}$ for yogurt with pineapples. As you can see, these figures are lower than those found in this study. 
Table 2: Minerals content of the yoghurt produced $(\mathrm{mg} / \mathrm{kg})$

\begin{tabular}{|c|c|c|c|c|c|c|c|c|c|}
\hline Sample & $\mathrm{Ca}^{+2}$ & $\mathrm{Na}^{+}$ & $\mathrm{K}^{+}$ & $\mathrm{Mg}^{+2}$ & $\mathrm{Fe}^{+3}$ & $\mathrm{Zn}^{+2}$ & $\mathrm{~Pb}^{+2}$ & $\mathrm{Mn}^{+2}$ & $\mathrm{Cd}^{+2}$ \\
\hline $\mathrm{YF}$ & $\begin{array}{c}2938,67 \\
\pm \\
21,54\end{array}$ & $\begin{array}{c}959,36 \\
\pm \\
41,72\end{array}$ & $\begin{array}{c}725,68 \\
\pm \\
63,67\end{array}$ & $\begin{array}{c}200,67 \\
\pm \\
12,71\end{array}$ & $\begin{array}{c}9,60 \pm \\
1,48\end{array}$ & $\begin{array}{c}7,93 \pm \\
0,589\end{array}$ & $\begin{array}{c}<0,42 \pm \\
0\end{array}$ & $\underset{0,05}{0,56 \pm}$ & $\begin{array}{c}<0,42 \pm \\
0\end{array}$ \\
\hline YB & $\begin{array}{c}2213,31 \\
\pm \\
17,85\end{array}$ & $\begin{array}{c}918,71 \\
\pm \\
7,73\end{array}$ & $\begin{array}{c}756,71 \\
\pm \\
22,73 \\
\end{array}$ & $\begin{array}{c}267,85 \\
\pm \\
32,42\end{array}$ & $\begin{array}{c}10,49 \pm \\
0,89\end{array}$ & $\begin{array}{c}2,74 \pm \\
0,34\end{array}$ & $\begin{array}{c}<0,36 \pm \\
0\end{array}$ & $\begin{array}{c}0,44 \pm \\
0,014\end{array}$ & $\begin{array}{c}<0,36 \pm \\
0\end{array}$ \\
\hline YM & $\begin{array}{c}2350,25 \\
\pm \\
27,33 \\
\end{array}$ & $\begin{array}{c}783,37 \\
\pm \\
20,58 \\
\end{array}$ & $\begin{array}{c}771,77 \\
\pm \\
22,18 \\
\end{array}$ & $\begin{array}{c}169,54 \\
\pm \\
8,65 \\
\end{array}$ & $\underset{1,28}{11,52} \pm$ & $\begin{array}{c}1,29 \pm \\
0,18\end{array}$ & $\begin{array}{c}<0,38 \pm \\
0\end{array}$ & $\begin{array}{c}0,49 \\
0.03\end{array}$ & $\begin{array}{c}<0,38 \\
0\end{array}$ \\
\hline YN & $\begin{array}{c}1950,41 \\
\pm \\
67,90\end{array}$ & $\begin{array}{c}684,72 \\
\pm \\
8,92\end{array}$ & $\begin{array}{c}540,58 \\
\pm \\
38,33\end{array}$ & $\begin{array}{c}132,16 \\
\pm \\
16,36\end{array}$ & $\begin{array}{c}5,26 \pm \\
1,21\end{array}$ & $\begin{array}{c}0,35 \pm \\
0,018\end{array}$ & $\begin{array}{c}<0,37 \pm \\
0\end{array}$ & $\begin{array}{c}<0,37 \pm \\
0\end{array}$ & $\begin{array}{c}<0,37 \pm \\
0\end{array}$ \\
\hline
\end{tabular}

YF: Yoghurt with the powder of Frezza date

YB: Yoghurt with the powder of Degla-Beida date YM: Yoghurt with the powder of Mech-Degla date YN: Yoghurt Nature

- The content of sodium YF is higher than YB, YM and $\mathrm{YN}$. It is $959.36(\mathrm{mg} / \mathrm{kg})$ against $918.77,783.37$ and $684.72(\mathrm{mg} / \mathrm{kg})$ for YB, YM, YN respectively. The sodium content in the plain yoghurt is also variable: $311 \mathrm{mg} / \mathrm{kg}$ (Wang and Singh, 1978), 480 $\mathrm{mg} / \mathrm{kg}$ (Souciet al, 1993) and $374 \mathrm{mg} / \mathrm{kg}$ ( Garcia Martinez et al,1998). (Sanchez-Segarra et al, 2000) have found concentrations of sodium of $385 \mathrm{mg} / \mathrm{kg}$ for a strawberry yogurt, $356 \mathrm{mg} / \mathrm{kg}$ for a yogurt with blackberries, $392 \mathrm{mg} / \mathrm{kg}$ for a yogurt added to a mixture of fruits, $303 \mathrm{mg} / \mathrm{kg}$ for a normal peaches yoghurt; $385 \mathrm{mg} / \mathrm{kg}$ for a yoghurt with yellow peaches, $354 \mathrm{mg} / \mathrm{kg}$ for a yogurt with red Peaches and $357 \mathrm{mg} / \mathrm{Kg}$ for the pineapple yogurt. The sodium content of our yoghurt is still double the values cited in the literature. It is in our view the only criterion of quality that may seem as apparent disadvantage of our formulations. However, as indicated in the following paragraph, this excess is largely compensated by a potassium deficiency.

- The potassium content of YM is higher with a value of $771.77 \mathrm{mg} / \mathrm{kg}$. For a plain yogurt, this value is $2174 \mathrm{mg} / \mathrm{Kg}$ (Wang and Singh, 1978) $1843 \mathrm{mg} / \mathrm{kg}$ and $1297 \mathrm{mg} \mathrm{/} \mathrm{kg} \mathrm{(Moreno} \mathrm{Rojas} \mathrm{et} \mathrm{al,} \mathrm{1993).}$ (Sanchez-Segarra et al, 2000) have found potassium concentrations of $1191 \mathrm{mg} / \mathrm{kg}$ for a strawberry yogurt, $1209 \mathrm{mg} / \mathrm{kg}$ for a yogurt with blackberries, $1337 \mathrm{mg} / \mathrm{kg}$ for a yogurt added to a mixture of fruits, $921 \mathrm{mg} / \mathrm{kg}$ for a normal peaches yoghurt, $1119 \mathrm{mg} /$ $\mathrm{kg}$ for a yogurt with yellow Peaches, $1135 \mathrm{mg} / \mathrm{kg}$ for a yogurt with red peaches, $1285 \mathrm{mg} / \mathrm{Kg}$ for the pineapple yogurt. These figures are higher than those found in this study. As already mentioned, there is an advantageous compensation between sodium and potassium.

- On magnesium, its content is higher in the case of YB $(267.85 \mathrm{mg} / \mathrm{kg})$ is more than 10 times the values listed in the bibliography. (Sanchez-Segarra et al, 2000) have found concentrations of magnesium, 94 $\mathrm{mg} / \mathrm{kg}$ for a strawberry yogurt, $101 \mathrm{mg} / \mathrm{kg}$ for a yoghurt with blackberries, $105 \mathrm{mg} / \mathrm{kg}$ for a yogurt added to a mixture of fruit, $82 \mathrm{mg} / \mathrm{kg}$ for a normal Peach yogurt, $84 \mathrm{mg} / \mathrm{kg}$ for a yoghurt with yellow Peaches, $86 \mathrm{mg} / \mathrm{kg}$ for a yogurt with red peaches, $97 \mathrm{mg} / \mathrm{Kg}$ for the pineapple yoghurt.

-The content of $\mathrm{Mg}$ in the plain yoghurt varies between 80 and $131 \mathrm{mg} / \mathrm{kg}$ (Buttriss, 1997). These results are similar to ours in terms of plain yogurt.

- The content of iron in the three yoghurts (YM, YB, and $\mathrm{YF}$ ) is almost identical and higher than $\mathrm{YN}$ : 9.6, $10.49,11.52$ and $5.26 \mathrm{mg} / \mathrm{kg}$ for YF, YB, YM and $\mathrm{YN}$ respectively. Moreover, these values are higher than those reported in the literature. It was indeed found that the amount of iron in the plain yogurt is 0.4 $\mathrm{mg} / \mathrm{kg}$ (Pennington and Young, 1990), $0.47 \mathrm{mg} / \mathrm{kg}$ and $0.5 \mathrm{mg} / \mathrm{kg}$ (Garcia Martinez et al, 1998), The yogurt is classified as a food of a less nutritional value because of its low contribution of iron in the diet value (Schneider, 1994). The addition of fruit pieces, especially strawberries, raspberries and wild blackberries cause an increase in the concentration of all minerals ( McCance et Widdowson, 1993). 
(Sanchez-Segarra et al, 2000) have found concentrations of iron de1.18 mg / kg for a strawberry yogurt, $3.46 \mathrm{mg} / \mathrm{kg}$ for a yogurt with blackberries, $1.06 \mathrm{mg} / \mathrm{kg}$ for a yogurt added with a mixture of fruit, $0.45 \mathrm{mg} / \mathrm{kg}$ for a yoghurt with normal peaches, 0.86 $\mathrm{mg} / \mathrm{kg}$ for a yogurt with yellow peaches, $0.62 \mathrm{mg} /$ $\mathrm{kg}$ for a yogurt with red Peaches and $0,78 \mathrm{mg} / \mathrm{Kg}$ for the pineapple yogurt.

- Concerning the zinc, YF is richer than other yogurts. This content is equal to $7.93 \mathrm{mg} / \mathrm{kg}$, while it is 2.74 (YB), 1.29 (YM) and $0.35(\mathrm{YT})$. These results on the date's yoghurt are not consistent with the bibliographic data. (Fiszman et al, 1997) have found concentrations of zinc de $3.2 \mathrm{mg} / \mathrm{Kg}$ for a strawberry yogurt, $3.2 \mathrm{mg} / \mathrm{kg}$ for a yogurt with blackberries, 3.5 $\mathrm{mg} / \mathrm{kg}$ for a yoghurt added to a mixture of fruit, 2.8 $\mathrm{mg} / \mathrm{kg}$ for a yoghurt with normal peaches, $2.8 \mathrm{mg} /$ $\mathrm{kg}$ for a yogurt with yellow peaches, $2.9 \mathrm{mg} / \mathrm{kg}$ for a yogurt with red peaches and $3.4 \mathrm{mg} / \mathrm{Kg}$ for the pineapple yogurt.

On the plain yogurt, the result is very low compared to data from the literature: $3.85-5.24 \mathrm{mg} / \mathrm{kg}$ (Buttriss, 1997), $5.5 \mathrm{mg} / \mathrm{kg}$ (Varo et al,1980), $4.6 \mathrm{mg} / \mathrm{kg}$ [11], 7 $\mathrm{mg} / \mathrm{kg}$ and $3.5 \mathrm{mg} / \mathrm{kg}$ (Garcia Martinez et al, 1998).

-The concentration of manganese is $0.56 \mathrm{mg} / \mathrm{kg}$ for YF, $0.44 \mathrm{mg} / \mathrm{kg}$ for $\mathrm{YB}, 0.49 \mathrm{mg} / \mathrm{kg}$ for YM and less than $0.37 \mathrm{mg} / \mathrm{kg}$ for $\mathrm{YN}$. These results (for the date's yoghurt) are consistent with those of literature: $0.041 \mathrm{mg} / \mathrm{Kg}$ [19], $0.03 \mathrm{mg} / \mathrm{kg}, 0.061 \mathrm{mg} / \mathrm{kg}$ (Moreno Rojas et al, 1993) and $0.061 \mathrm{mg} / \mathrm{kg}$ (Garcia Martinez et al, 1998). The plain yogurt is considered as a food which is poor of Manganese (Garcia Martinez et al, 1998). The addition of pieces of strawberries and a mixture of fruit or blackberries increases the amount of Mn by 10-20 times and the addition of pineapple chunks between 40 and 80 times in the final composition of yoghurt.

- The contents of $\mathrm{Pb}$ and $\mathrm{CD}$ are almost identical in all the four yoghurts. They are less than $0.36 \mathrm{mg} / \mathrm{kg}$. This prompts us to conclude that $\mathrm{Pb}$ and $\mathrm{CD}$ come mainly from the milk used. There are traces in date's fruit.

In all our results (except $\mathrm{Na}$ and $\mathrm{K}$ ) are close to those found by (De La Fuente et al, 2003) in various market yoghurt. They reported values between 1547-2338l $\mathrm{mg} / \mathrm{kg}$ for K, 476-777 mg / kg for Na, 101-177 mg / $\mathrm{kg}$ for $\mathrm{Mg}, 1088-2050$ for Ca.

Conclusion: Large concentrations of minerals are found in all the three yoghurt-based on the powdered dates. We can say that the addition of powdered dates of the three cultivars (Mech-Degla, DeglaBeida and Frezza) in the yogurt as a substitute of granulated sugar, allows enriching yoghurt with minerals ( $\mathrm{Ca}$, Nas, $\mathrm{K}, \mathrm{Mg}, \mathrm{Zn}$, in particular elements which are deficient in the milk: Fe and $\mathrm{Mn}$ ).

\section{REFERENCES}

Benamara, S., Chibane, H., Boukhlifa, M (2004). Essai de formulation d'un yaourt naturel aux dattes, IAA. Actualités techniques et scientifiques, $N^{\circ} 1 / 2$ mensuel, 11-14.

Buelguedj, M (1996). Caractéristiques des cultivars de dattiers du Sud-Est du Sahara algérien. Vol I. Conception et réalisation : Filière "Cultures pérennes" de I'ITDAS.

Buttriss, J (1997). Nutritional properties of fermented milk products, International Journal of Dairy Technology. $50: 21-27$.

De la Fuente, M. A., Montes, F., Guerrero, G., Juarez, M (2003). Analytical, Nutritional and Clinical Methods, Total and soluble contents of calcium, magnésium, phosphorus and zinc in yoghurts, Food Chemistry .80: 573-578.

El Nakhal, H., El Sharawy, M. I., Messalem, A.S (1987). Amarheep a new product from dates 'tmar) with hight protein content, The date palm Journal, FAO, Vol. 5 (1) : 92-106.

Fiszman, S. M., Lluch ,M. A., Salvador, A (1999) . Effect of addition of gelatine on microstructure of acidic milk gels and yoghurt and on their rheological properties, International Dairy Journal. 9: 895-901.

Garcia Martinez, M., Sanchez Segarra, P. J., Gordillo Otero, M. J.,Amaro Lopez ,M. A., Moreno-Rojas, R (1998) . Valoracionnutricional de la composicion mineral de yogures enteros aromati-zados. Alimentaria. 297: 73-76.

Greiner, D (1998). The market of date, product of revenue of the oases: in plays, diversity, tension. Books Dryness, Vol.9, N²3: 155-162.

McCance et Widdowson, The composition of foods (5th revised and extended Ed.). Cambridge, UK (1993). The Royal Society of Chemistry and Ministry of Agriculture, Fisheries and Food.

Mikki, M. S., Al Taisan, S. M., Abdulaziz, A. A 1987) Incorporation of date pulp for the manufacture of tomato kechup. The Date Palm Journal, FAO, Vol.5 (2): 215-216.

Moreno Rojas, R., Canal Ruiz, C., Amaro Lopez, M. A., Zurera Cosano, G (1993) Contenido mineral del yogur natural, Alimentaria. 239: 81-84.

Pennington, J. A. T. et Young, B (1990) .Iron, zinc, copper, manganese, selenium, and iodine in foods from United 
States total dietstudy. Journal of Food Composition and Analysis. 3: 166-184.

Sanchez-Segarra, P. J, Garcia-Martinez, M., GordilloOtero, M.j., Diaz-Valverde, A., Amaro-Lopez, M.A., Moreno-Rojas R (2000). Influence of addition of fruit on the mineral content of yoghurts: nutritional assessment, Food Chemistry. 70: 85-89.

Schneider, E (1994). La leche y sus derivados. In La salud por la Nutricion, Madrid: Safeliz, Vol. 2 : 763-791.

Siboukeur, O (1997). Qualité nutritionnelle, hygiénique et organoleptique du jus de dattes. Thèse Magister, INA. El-Harrach, Alger, 106 p.

Souci, S.W., Fachmann, W. Kraut, H (1993). Food composition and nutrition tables (5th revised and completed ed.) (Deutsche For-schungsanstalt fuÈ $r$
Lebensmittelchemie, Garching b. MuÈ nchen)(compiled by H. Scherz \& F. Senser) Stuttgart: Medpharm Scienti®cPubl.; Boca Raton, Ann Arbor, London, Tokyo: CRC Press,.

Tamime, A Y., Robinson, R K (1985). Background to manufacturing practice, In Tamime A. Y. \& Robinson R. K. (Ed.), Yoghurt. Science and technology, Pergamon Press, Paris, 7-90.

Varo, P., Nuurtamo M.., Saari, E., Koivistoinen, P (1980). Mineral element composition of Finnish foods. VII. Dairy products, eggs and margarine. Acta Agriculture Scandinavica, 22 : 115-126.

Wang, C.Y., Singh, R. P (1978). A single drying equation for rough rice, Transactions of American Society of Agricultural Engineers, 11: 668-672. 